\title{
Influence of the social context in smoking during pregnancy
}

\author{
Influência do contexto social na manutenção do tabagismo em gestantes \\ La influencia del contexto social em el mantenimiento del tabaquismo en el embarazo
}

\section{Lucíola D'Emery Siqueira' \\ ORCID: 0000-0001-5087-9824 \\ Lislaine Aparecida Fracolli' ORCID: 0000-0002-0936-4877}

Sayuri Tanaka Maeda' ORCID: 0000-0002-6571-6523

'Universidade de São Paulo. São Paulo, São Paulo, Brazil.

How to cite this article:

Siqueira LD, Fracolli LA, Maeda ST. Influence of the social context in smoking during pregnancy.

Rev Bras Enferm. 2019;72(Suppl 3):259-65. doi: http://dx.doi.org/10.1590/0034-7167-2018-0619

\section{Corresponding Author:}

Lucíola D'Emery Siqueira

E-mail: luciola.demery@gmail.com

Submission: 10-05-2017 Approval: 03-02-2019

\begin{abstract}
Objective: to know the social and family relationships of pregnant women and to analyze their influence in keep smoking during pregnancy. Method: it is a descriptive-exploratory study with a qualitative approach, which had as subjects 10 pregnant smokers. Data were collected from January to March / 2015, through interviews, and organized into graphical representations of the genogram/ecomap and discourse units. Results: pregnant women had low educational level, precarious insertion in the work market and relations of great dependence of the family. Tobacco consumption integrates the family environment and is viewed naturally in the sociocultural environment. In prenatal care, there was no coordinated and longitudinal intervention for smoking cessation. Conclusion: smoking cessation is strongly influenced by the social environment, and the family is an important component of this network. In this sense, strategies to approach smoking should allow a reflection of the norms and rules of the family.
\end{abstract}

Descriptors: Smoking; Pregnant Women; Nursing; Primary Health Care; Social Network.

\section{RESUMO}

Objetivo: conhecer as relações sociais e familiares de gestantes e analisar sua influência na manutenção do tabagismo, durante a gestação. Método: trata-se de um estudo descritivoexploratório com abordagem qualitativa, que teve como sujeitos 10 gestantes tabagistas. Os dados foram coletados de janeiro a março/2015, por meio de entrevistas, e organizados em representações gráficas do genograma/ecomapa e unidades de discurso. Resultados: as gestantes tinham baixa escolaridade, precária inserção no mercado de trabalho e relações de grande dependência da família. $O$ consumo do tabaco integra o ambiente familiar e é encarado com naturalidade no meio sociocultural. Na assistência pré-natal, constatou-se inexistência de uma intervenção coordenada e longitudinal para a cessação do tabagismo. Conclusão: a cessação do tabagismo sofre forte influência do meio social sendo a família um importante componente dessa rede. Nesse sentido, as estratégias para abordagem do tabagismo devem possibilitar uma reflexão das normas e regras da família. Descritores: Tabagismo; Gestantes; Enfermagem; Atenção Primária à Saúde; Rede Social.

\section{RESUMEN}

Objetivo: conocer las relaciones sociales y familiares de mujeres embarazadas y analizar su influencia en el mantenimiento del tabaquismo durante el embarazo. Método: se trata de un estudio descriptivo-exploratorio con abordaje cualitativo, lo cual tuvo como sujetos 10 mujeres embarazadas tabaquistas. La recolección de datos ocurrió desde enero hasta marzo 2015, por medio de entrevistas. Fueron organizados en representaciones graficas del genograma/ecomapa y unidades de discurso. Resultados: esas mujeres tenían baja escolaridad, precaria inserción en el mercado de trabajo y relaciones de gran dependencia con su familia. El consumo del tabaco integra el ambiente familiar y se ve con naturalidad en el medio sociocultural; en la asistencia prenatal, se constató la inexistencia de una intervención coordinada y longitudinal para el cese del tabaquismo. Conclusión: el cese del tabaquismo sufre una fuerte influencia del medio social, siendo la familia un importante componente de esa red. En este sentido, las estrategias para el abordaje del tabaquismo deben posibilitar una reflexión de las normas y reglas de la familia.

Descriptores: Tabaquismo; Mujeres Embarazadas; Enfermería; Atención Primaria de Salud; Red Social. 


\section{INTRODUCTION}

By 2015, more than six million global deaths were attributed to tobacco use. Although studies point to a worldwide reduction in consumption over the last 25 years, with a prevalence of $25 \%$ for men and 5.4\% for women, smoking is still among the top five risk factors for adjusted years of lost life for disabilities ${ }^{(1)}$. The impact of the Framework Convention on Tobacco Control (FCTC), a document signed by almost 200 countries in the reduction of consumption, for implementing actions that cover the entire production chain of cigarettes, with measures ranging from agricultural production to taxes insertion and restriction of advertising in media vehicles ${ }^{(2)}$. Although the document was well implemented in Brazil, the reduction in prevalence was more noticeable among men and individuals belonging to the higher socioeconomic strata ${ }^{(3)}$.

Recent evidence demonstrates the gender disparity in tobacco use. Globally, men consume four times as much tobacco compared to women, with this difference being smaller in the Americas (1.6 times) and higher in the Western Pacific (11.4 times) ${ }^{(4)}$. Even with these data pointing to a lower consumption in numbers for women, a gender analysis imposes on women a situation of vulnerability that predisposes them to an early initiation and difficulties in quitting smoking ${ }^{(5)}$.

Data related to morbimortality due to tobacco use indicate that both male and female users suffer from tobacco-induced diseases such as lung cancer, chronic obstructive disease, lung disease and cardiovascular disease. However, additional risks to women's health demonstrate a higher prevalence of cervical cancer, low bone density, pregnancy-related problems and heart disease associated with the concomitant consumption of hormonal contraceptive methods ${ }^{(4)}$.

Factors that lead pregnant women to smoking are strongly associated with socioeconomic conditions $s^{(6-7)}$. A study on the prevalence of smoking in Brazilian pregnant women showed that $18 \%$ remained smoking during pregnancy, with a low prevalence of cessation, mainly among black women, low income and with less education ${ }^{(8)}$. Canada, England and the United States implement an effective smoking cessation policy during gestation due to the high cost of the health system for the treatment of the occurrences of smoking during pregnancy. It is known that the deleterious effects of the substances present on the cigarette impact on the intrauterine growth and development of the child, increasing the chances during pregnancy of adverse events for the mother and fetus ${ }^{(9)}$.

Prenatal care at Primary Care advocates approaching the problem of smoking in preconception consultations, through qualified listening, which favors the linkage and avoids judgments regarding the use of tobacco and other drugs during gestation, being a propitious moment for abandonment of smoking ${ }^{(9)}$.

There are few studies that seek to understand and explain the influence of social, family, and community relations on maintaining smoking during pregnancy. A study that analyzed the influence of the social network on the maintenance of smoking in gestation showed that having family and friends smokers, perception of insecurity in the neighborhood and a situation of food insecurity, strongly decreases the chances of smoking cessation ${ }^{(10)}$. It was also identified that women with smoker relatives and friends were more likely to return to smoking in the puerperium ${ }^{(11)}$.
In light of the above, there is still no clarity about the sociocultural and family factors that influence women to remain smoking during pregnancy, becoming an intriguing scientific gap. Thus, qualitative studies can help to clarify this problem, by valuing the cultural heterogeneity of the Brazilian population and the gender issues to which the woman is subjected in society.

In order to contribute to this discussion, the following question was raised: does family and community relations of pregnant women influence whether or not smoking continues during pregnancy? For this study, the theoretical framework of health promotion was used, specifically the Labonte's model, which brings the interrelation of dimensions and interfaces that express the complexity of the healthdisease process. This model goes beyond biomedical approaches and considers biopsychosocial aspects to be relevant in the process ${ }^{(12)}$.

\section{OBJECTIVE}

To know the social and family relationships of pregnant women and to analyze their influence in keep smoking during pregnancy.

\section{METHOD}

\section{Ethical aspects}

All participants were informed about the research and signed the Free and Informed Consent Form after endorsement by the Ethics Committee of the Universidade de São Paulo's School of Nursing, pursuant to Resolution 466/12 of the National Health Council. To maintain anonymity, the names of participants were fictitious.

\section{Type of study}

This is a descriptive-exploratory study with the qualitative approach.

\section{Methodological procedures}

\section{Study setting}

The study was developed in health units with Family Health Strategy, in the eastern region of the city of São Paulo. The choice of this region was due to socioeconomic indicators of high vulnerability and to be among the regions with the highest rates of birth and fertility in the municipality, infant and neonatal mortality rates above the municipal average $\mathrm{e}^{(13)}$. Although the city does not have the prevalence of pregnant smokers in the region, situations of high social vulnerability are prone to tobacco consumption ${ }^{(1)}$. Therefore, it is justified to choose the research setting.

\section{Data source}

The selection of the sample was for convenience, that is, it was the family health team that indicated possible participants. The study subjects were 10 pregnant women. Participants had prior knowledge of the research objective. After being accepted to participate in the study, it was scheduled one day for the researcher to go to the participant's home. Three pregnant women refused to participate in the study. The inclusion criteria of the participants were: (a) to be pregnant; (b) 
smoke tobacco regularly; (c) to be able to participate in the interview (from an emotional, intellectual and physical point of view).

\section{Collection and organization of data}

Data were collected in two ways: 1) through the construction of the genogram and the ecomap and 2) through a semi-structured individual interview. The interviewer was the researcher herself, a nurse with specialization in Collective Health, and familiar with the theme. Data were collected at home, in a private place, without the presence of other family members and/or the Community Health Agent, from January/2015 to March/2015. The information collected was recorded and transcribed later. They had as their driving force: how tobacco consumption began, how tobacco consumption was being experienced at the time of gestation, and how the pregnant woman perceived the people's opinion about her living together about tobacco consumption. Interviews lasted, on average, 65 minutes, and vocabulary adaptations were made to better understand socio-cultural and educational contexts. After the approach of 10 pregnant women, it was observed that the data reported were repetitive. Therefore, it was decided to close data collection with this number of subjects.

\section{Data analysis}

Data were analyzed in two different ways. First, based on the characterization of relationships described in the genograms and ecomaps ${ }^{(14)}$ constructed with the pregnant woman during data collection. Second, based on the themes that emerged from the interview reports and analyzed by the thematic content analysis ${ }^{(15)}$. The intersection of results from the interpretation of the genogram/ecomap and reports on smoking allowed us to identify points where smoking and the family/social context were potentialized. The analysis of these points of intersection generated two categories: (1) Family Relations: a strong influence and (2) Social Relations: an influence to be built.

The analytical aim of this research is to add interpretative value to the construction of the genograms and ecomaps, understanding that this allows a better visualization and understanding of the family relationships and the community network of the pregnant woman, and how they influence (or not) the consumption of tobacco. Genogram is a tool that helps in the interpretation of the problems that affect the members of the family, as well as allows the visualization of sources of resistance, strengthening, resilience and potential resources. The information contained therein is embedded in a cultural, political, spiritual and socioeconomic context of its members, and can be found both horizontally in the family context and vertically across generations ${ }^{(14)}$. With the ecomaps, it is possible to visualize several people and institutions that participate in the network of health care, being fundamental for the planning of the actions, considering the particularities of that family ${ }^{(16)}$. Tools capable of representing "feelings", "perceptions", "impressions" are essential resources in research that seek to understand and interpret "lived" realities when the subject/interviewee often has difficulties expressing themselves verbally given their social vulnerabilityl[ ${ }^{(17)}$.

The graphical representation through the genogram and ecomap consists of a drawing where the family positions itself in a central circle and circles around are constructed representing people, organs or institutions that contextualize the individual and his family. Genopro software was used to aid in the diagramming of the figures. This software has the ability to construct the graphical representation of the genogram and ecomap from the inclusion of information about family members, as well as to create a dynamic database ${ }^{(14)}$. The software uses its own symbology, which is described in Figure 1.

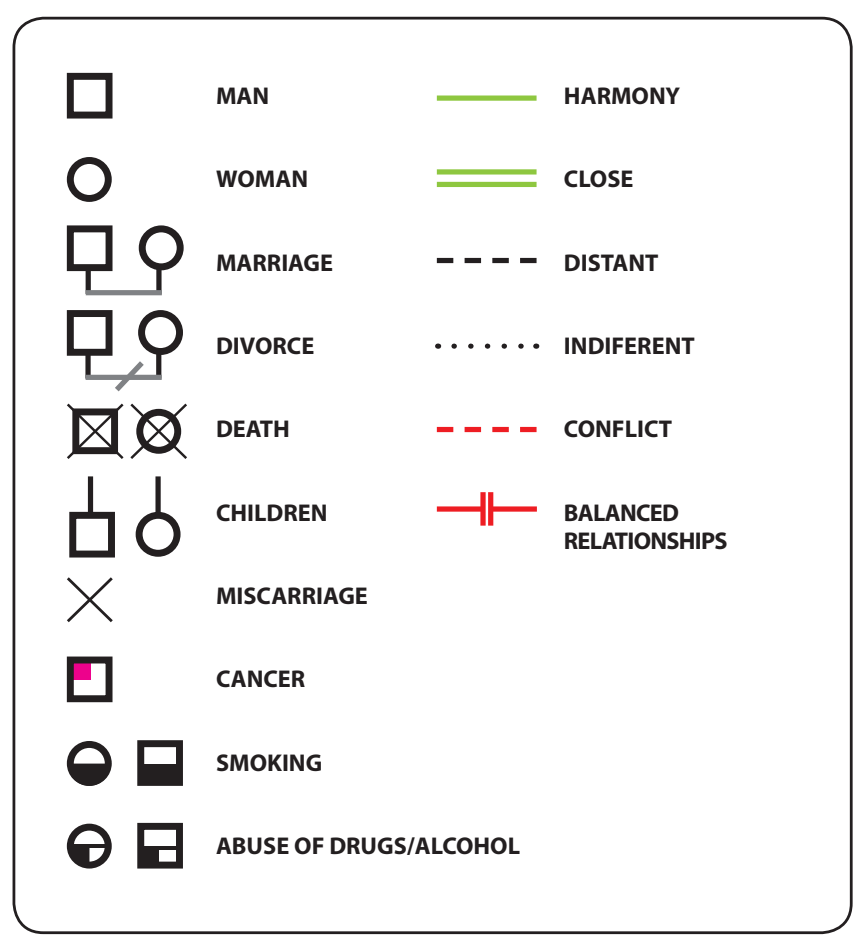

Source: Genopro" software. Available from: http://www.genopro.com/

Figure 1 - Description of the symbols used in the construction of the genogram and ecomap, São Paulo, São Paulo, Brazil, 2015

\section{RESULTS}

\section{Population characterization}

Participants had, on average, 28.7 years, most of them with schooling until high school, and married. As for the profession, they worked as maids, cleaning assistants and kitchen assistants, mostly with precarious employment relationships (Table 1). The family nucleus consisted mainly of spouses and children. In some families, there were cohabitation of other members, such as mothers and mothers-in-law, mainly due to a precarious housing situation and the need to subdivide the rooms of the house.

Table 1 - Sociodemographic and clinical profile of participants $(N=10)$, São Paulo, São Paulo, Brazil, 2015

$\begin{array}{cr}\text { Marital Status } & \\ \text { Married } & 08 \\ \text { Single } & 02\end{array}$

Schooling
$5-8$ years
$>8$ years 


\begin{tabular}{|c|c|}
\hline & $\mathbf{n}$ \\
\hline \multicolumn{2}{|l|}{ Age } \\
\hline $20-29$ years & 06 \\
\hline $30-38$ years & 04 \\
\hline \multicolumn{2}{|l|}{ Smoking during pregnancy } \\
\hline Maintained the same consumption & 02 \\
\hline Increased consumption & 02 \\
\hline Decreased spontaneously & 02 \\
\hline \multicolumn{2}{|l|}{ Profession } \\
\hline Maid & 02 \\
\hline Business Analyst & 04 \\
\hline Unemployed & 04 \\
\hline \multicolumn{2}{|l|}{ Gestational Age } \\
\hline 1st quarter & 01 \\
\hline 2nd quarter & 03 \\
\hline 3rd quarter & 06 \\
\hline \multicolumn{2}{|l|}{ No of prenatal appointments } \\
\hline 01-02 appointments & 02 \\
\hline 03-04 appointments & 06 \\
\hline 05-06 appointments & 02 \\
\hline
\end{tabular}

\section{Family Relationships: a strong influence}

The families of the pregnant women are structured under a network of care that involves several generations. Although the nuclear family is present in the family structure of most participants, the integration of the kinship network is fundamental in the conduct of routine activities. Faced with marital relations and unstable economic situation, as perceived in families, the family arrangement integrates generations and transcends the nuclear family model. The genogram of pregnant woman Luciana exemplifies this family arrangement (Figure 2). Although some family relationships express "distancing", "indifference" or "conflict" in the genogram, they make up the pregnant woman's support network, mainly due to the socioeconomic condition experienced.

In relation to tobacco consumption, the presence of smoking in the family environment is evident. All participants live with smokers and/or had smokers' parents. It is noticed that the pregnant women are involved in a social environment prone to smoking. There is a pattern of consumption that crosses generations and seems to be viewed naturally in family norms.

The construction of genograms and ecomaps also allowed the visualization of the social network close to the pregnant woman and, from this, some considerations can be drawn. There is precariousness in the institutions/people that compose the social network. The Basic Health Unit (BHU) was represented as a "harmonic" link in all genograms. It can be inferred that pregnant women recognize the health service as a genuine source of support and that it meets the needs of their family (Figure 3). The School and Daycare Center were also present, the first representing a current situation of "detachment", mainly due to the interruption of studies due to the current or previous pregnancy. The daycare center was represented by a "harmonic" relationship, mainly by women who depend on this service to support them in day-to-day care of the other children (Figure 4).

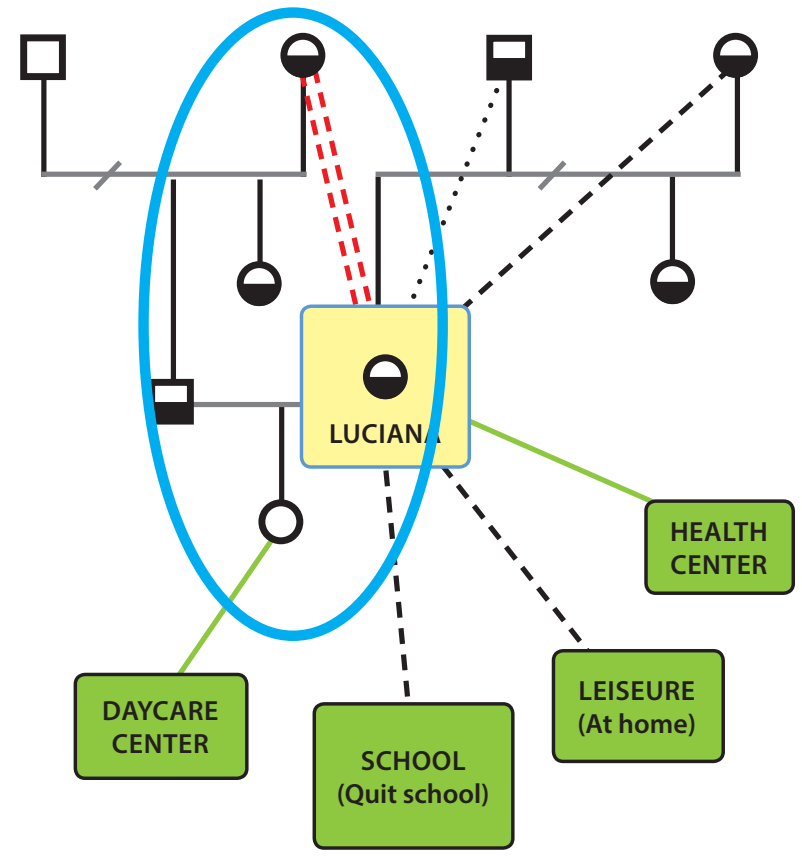

Figure 2 - Graphical representation of the genogram/ecomap of the pregnant woman Luciana, São Paulo, São Paulo, Brazil, 2015

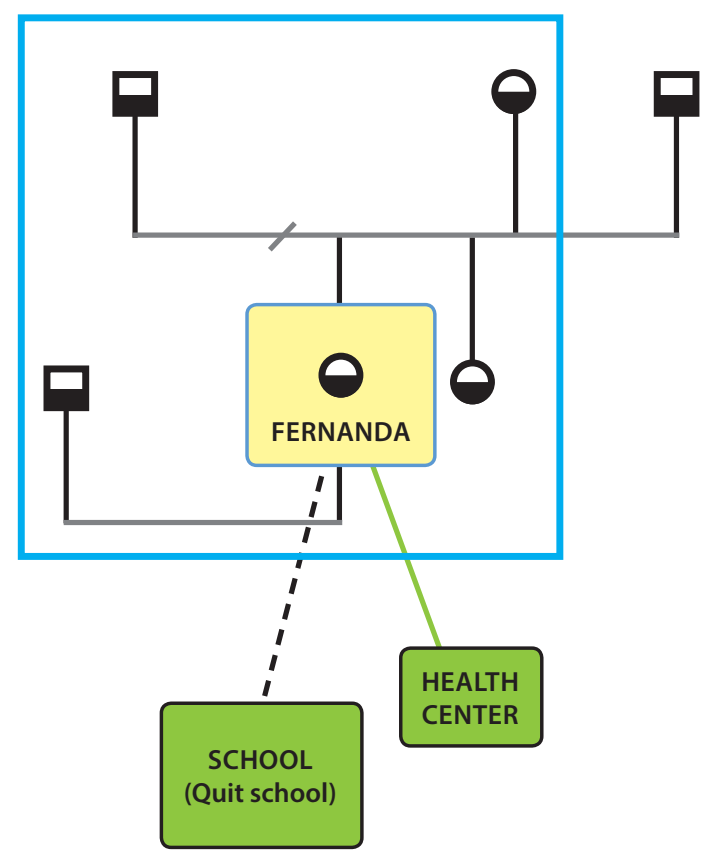

Figure 3-Graphical representation of the genogram/ecomap of the pregnant woman Fernanda, São Paulo, São Paulo, Brazil, 2015

\section{Social Relations: an influence to be built}

By understanding that leisure is essential to minimize stress and, when present, may contribute to smoking cessation, it has been portrayed in the ecomaps. In most situations, leisure was restricted to the domestic environment. It can be inferred that the scarce availability of leisure options in the neighborhood, the distancing of the central region of the city where leisure facilities are concentrated, and violence associated with drug trafficking 


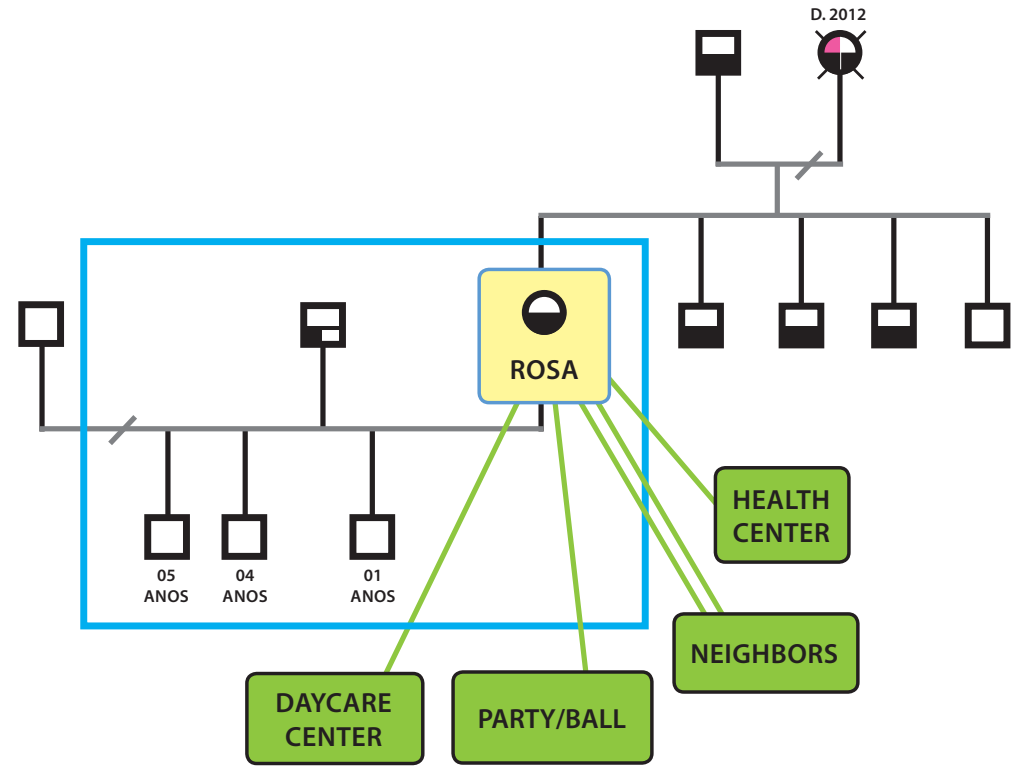

Figure 4 - Graphical representation of the genogram/ecomap of the pregnant woman Rose, São Paulo, São Paulo, Brazil, 2015

in the neighborhood can restrict leisure time at home (Figure 2). Contrary to this, neighbors emerged in the ecomaps in a positive way, as people very present in the routine of pregnant women, which broadens their care network (Figure 4). The established links were portrayed as "close" and "harmonic", in some cases, having better relations than with the family itself.

The ecomaps analysis evidenced a satisfaction with the service rendered by the health service. However, the statements show that smoking during pregnancy did not mobilize the multiprofessional team to intervene in the reduction/cessation. Therefore, there is no coordinated and longitudinal intervention for the smoking cessation and, when present, it was fragmented and punctual.

[...] at the prenatal care, I have already had three visits and they did not even ask if I smoked. I intend to quit smoking, because I hear a lot on television that cigarettes are bad, but I think I can stop [...]. (Luciana)

[...] at the first appointment, CHA and the doctor asked if I smoked, except that I was not smoking because I was sick. I then went back to smoking again [...]. (Mariah).

[...] here, at the health center, no one talked about it. I went to the doctor once and now l'm going to go with the nurse, then, maybe, tomorrow, maybe she'll say something [...]. (Paula)

[...] at the health center, they just asked if I smoked. I'm treating and fixing my teeth. I think she knows I smoke [...]. (Priscila)

[...] at the prenatal clinic, the doctor told me not to smoke and sent me to the group of pregnant women, but I did not go [...]. (Dora)

During prenatal care, a window of opportunity for smoking cessation/reduction is opened, since there is a strong sense of guilt that causes the woman to seek to justify smoking, demonstrating that despite smoking, she is aware of the harmful effects of tobacco. Pregnant women also complain of symptoms arising from the act of smoking.

[...] I intend to quit smoking, because I hear a lot on television that cigarettes are bad, but I think I can stop [...]. (Luciana)

[...] I know it's bad, even more so now, because I'm pregnant. Yesterday, I think I exaggerated because I have a strong taste of cigarette in my mouth [...]. (Priscila)

[...] / know I could not smoke in pregnancy, but it's addiction. I have bronchitis, when it strikes, I get very ill. The breath is panting, the cigarette is a plague. Yuck! I want to stop smoking [...]. (Dora)

\section{DISCUSSION}

Results showed that the family and community relations of pregnant smokers influence the maintenance of the smoking habit during pregnancy.

The population studied had low schooling, precarious insertion in the labor market, economic dependence of other family members and low family income. A study that correlated smoking with socioeconomic conditions in Canadian women showed that a low family income has a strong relation with smoking when compared to women with high family income ${ }^{(18)}$. A study of factors associated with maintenance of smoking during pregnancy with Chinese women showed that the lower the schooling, the greater the chances of the woman remaining smoking during pregnancy ${ }^{(19)}$. According to a study conducted in Brazil, a high educational level of the pregnant woman and her partner is more prone to free cigarette families. Women with low schooling have less control of smoking in the family environment and are more likely to passive smoking ${ }^{(20)}$. In fact, the health-disease process is a complex reality, as proposed by the Labonte's model. Therefore, it would be important for prenatal educational interventions to take health from the social determination of certain behaviors considered as unhealthy.

Results showed that the smoking habit in the families of the pregnant women interviewed is something that lasts for generations, seen naturally in the norms of family life. By studying the prevalence of smoking and its association with relationships established in families, it was observed that when tobacco consumption was indiscriminate inside and outside the family environment, often, regardless of the presence of children, the percentage of smokers among the members of the family was high $^{(20)}$. Thus, it is clear the need for prenatal care to operate from the recognition of the pregnant woman as a subject endowed with self-will, but with limitations in the expression of their autonomous decisions as a consequence of their belonging to a family context that naturally faces the habit of smoking. In this sense, strategies to approach smoking cessation should allow a reflection of the norms and rules of the family and not only the behavior of a member in isolation.

Regarding leisure, it was observed in the ecomaps the scarcity of leisure/relaxation activities and, when present, restricted to the domestic environment. A study that implemented activities related to leisure/relaxation as a strategy for smoking cessation, 
showed that the intervention was beneficial in smoking cessation reduction/cessation. It was also considered relevant to involve family and friends as partners for more effective action ${ }^{(21)}$. Interventions for smoking cessation should go beyond biomedical and behavioral approaches, acting in community life with intersectoral actions.

In contrast, results showed that prenatal care does not have coordinated and longitudinal interventions for smoking cessation, restricting itself to punctual and fragmented actions centered on the pregnant woman. Thus, the opportunity to improve the health of women is lost because pregnancy can be a propitious moment for changes in health-related behaviors, and prenatal care plays a key role in this awareness-raising process.

The information received during prenatal care on smoking mobilized pregnant women to think about quitting smoking ${ }^{(20)}$. However, a qualitative study that investigated barriers to the smoking cessation process in Canada concluded that the pregnant woman does not feel ready for cessation, since this habit is part of her lifestyle and family, helping to overcome difficulties due to the precarious socioeconomic conditions in which they live ${ }^{(22)}$. When realizing the pregnancy, the woman has little time to abandon a habit so ingrained in family and personal life. In this way, health education practices, with a view to health promotion, play an important role in the empowerment of pregnant women, so that the approach favors the construction of both individual and collective knowledge, as it allows reflection on their choices and decision-making. When considering family and community relations in prenatal care, smoking cessation actions should encourage family involvement, enable access to cessation methods, and include new approaches to treatment such as harm reduction.

However, the limits on health team knowledge and skills for smoking cessation counseling lead to a strongly persuasive approach for pregnant women to stop smoking. This forceful action can be perceived by the woman as a barrier to habit change ${ }^{(23)}$. It is necessary to re-evaluate the unilateral approach, which does not emphasize the social and family life context of the smoker, disregarding the social determinants of health ${ }^{(24)}$. A systematic review of family-based approaches to smoking cessation in specific groups, such as smoking couples, smoking parents, smokers, and pregnant women showed strong influence of family members on behavioral change in relation to smoking. It also found that approaches that aggregate the family are scarce and lack appropriate methodologies ${ }^{(25)}$.

Women need to deal with a set of pressures from themselves, the family, the media and health professionals, which are a motivational reinforcement for a reflection on tobacco consumption. However, what is perceived is a valuation of negative incentives, such as the over-pressure of people around and strongly persuasive approaches. In addition to the absence of therapeutic alternatives, it causes them to experience alone the distress caused by this conflict.

\section{Study limitations}

This study had as limitations a homogeneous sample from the socioeconomic point of view, which may characterize that the findings may be related to this profile analyzed. Another limitation was the small sample surveyed.

\section{Contributions to the fields of Nursing and Health}

This study contributes to the elucidation of relevant questions about the permanence of smoking during pregnancy and the strong influence of the social determinants in the cessation process. It brings the relation of smoking with several questions of life in society that can help the health team to draw strategies that approach the social reality of pregnant smoker. Considering the relevant role of nursing in the follow-up to the pregnant woman and her family at Primary Care, such knowledge makes it possible to broaden the perspective of the smoking approach in pregnancy and to include the sociocultural network and especially the pregnant woman's family in smoking cessation strategies.

\section{CONCLUSION}

In prenatal care at Primary Care, health professionals will face this complexity of sociocultural factors involved in maintaining smoking. Esses fatores se relacionam com intensos conflitos e sofrimento emocional, agravados pelas precárias condições socioeconômicas. In order to meet these demands, in addition to the knowledge of appropriate techniques for reduction/ cessation, professionals need sensitivity to sociocultural factors related to smoking among pregnant women and difficulties in dealing with the problem.

Family is an important component in the pregnant woman's social network and, in many cases, there is no social support relationship to the pregnant smoker. What is perceived is a transgenerational pattern in tobacco consumption. In this sense, strategies to approach smoking should allow a reflection of the norms and rules of the family, not only of a single member.

Results presentation shows that the motivations for smoking or quitting smoking are varied and strongly influenced by the social environment. This information can be useful in the context of health education. Addressing smoking in prenatal care means providing moments of reflection about women's choices and their own life as well as increasing their ability to control their life.

\section{REFERENCES}

1. Global Burden of Disease 2015 Tobacco Collaborators. Smoking prevalence and attributable disease burden in 195 countries and territories, 1990-2015: a systematic analysis from the Global Burden of Disease Study 2015. Lancet. 2017;389(10082):1885-906. doi: 10.1016/ S0140-6736(17)30819-X

2. Kastler F. Dez anos da Convenção-Quadro de Controle do Tabaco: a função normativa da OMS em socorro da saúde global? Rev Direito Sanit. 2016;17(1):54-99. doi: 10.11606/issn.2316-9044.v17i1p54-99 
3. Iglesias R, Jha P, Pinto M, Silva VLC, Godinho J. Documento de discussão - saúde, nutrição e população (HNP). Controle do tabagismo no Brasil: resumo executivo. Epidemiol Serv Saúde. 2008;17(4):301-4. doi: 10.5123/S1679-49742008000400007

4. World Health Organization (WHO). Gender, health, tobacco and equity [Internet]. Geneva: WHO; 2011 [cited 2017 July 30]. Available from: http://www.who.int/tobacco/publications/gender/gender_tobacco_2010.pdf?ua=1

5. Clair C, Kleijn MJ, Jaunin-Stalder N, Cornuz J. Gender and disparities: the example of tobacco smoking. Rev Med Suisse. 2015;11(478):1298-303

6. Schroeder SA. American health improvement depends upon addressing class disparities. Prev Med. 2016;92:6-15. doi: 10.1016/j.ypmed.2016.02.024

7. Bauld L, Graham H, Sinclair L, Flemming K, Naughton F, Ford A, et al. Barriers to and facilitators of smoking cessation in pregnancy and following childbirth: literature rewiew and qualitative study. Health Technol Assess. 2017;21(36):1-158. doi: 10.3310/hta21360

8. Dias-Damé JL, Juraci AC. Disparities in prevalence of smoking and smoking cessation during pregnancy: a population-based study. Biomed Res Int. 2015;2015:345430. doi: 10.1155/2015/345430

9. Ministério da Saúde (BR). Secretaria de Atenção à Saúde. Departamento de Atenção Básica. Atenção ao pré-natal de baixo risco [Internet]. Brasília: Ministério da Saúde; 2012 [cited 2017 July 30]. (Cadernos de Atenção Básica, n 32). Available from: http://bvsms.saude.gov.br/bvs/ publicacoes/cadernos_atencao_basica_32_prenatal.pdf

10. Castro Y, Heck K, Forster JL, Widome R, Cubbin C. Social and environmental factors related to smoking cessation among mothers: findings from the Geographic Research on Welling (Grow) study. Am J Health Behav. 2015;39(6):809-22. doi: 10.5993/AJHB.39.6.9

11. Homish GG, Eiden RD, Leonard KE, Kozlowski LT. Social environmental factors related to prenatal smoking. Addict Behav. 2012;37(1):73-7. doi: 10.1016/j.addbeh.2011.09.001

12. Labonte RN. Health promotion and empowerment: practice frameworks. Toronto: Centre for Health Promotion, University of Toronto; 1993.

13. São Paulo (cidade). Prefeitura Municipal de São Paulo. Secretaria Municipal de Saúde. Atlas da Saúde da Cidade de São Paulo [Internet]. São Paulo: Instituto Via Pública; 2011 [cited 2017 July 30]. Available from: https://www.prefeitura.sp.gov.br/cidade/secretarias/upload/saude/ arquivos/publicacoes/atlas_da_saude_da_cidade_de_sao_paulo_2011.pdf

14. McGoldrick M, Gerson R, Petry S. Genogramas avaliação e intervenção familiar. 3a ed. Porto Alegre: Artmed; 2012.

15. Bardin L. Análise de Conteúdo. Lisboa: Edições 70; 2009.

16. Musquim CA, Araujo L, Bellato R, Dolina J. Genograma e ecomapa: desenhando itinerários terapêuticos de família em condição crônica. Rev Eletrônica Enferm. 2013;15(3):656-66. doi: 10.5216/ree.v15i3.17730

17. Wright LM, Leahey M. Como documentar as entrevistas com a família. In: Enfermeiras e Família. Um guia para avaliação e intervenção na família. 3a ed. São Paulo: Roca; 2002. p 273-300.

18. Smith P, Frank J, Mustard C. Trends in educational inequalities in smoking and physical activity in Canada: 1974-2005. J Epidemiol Community Health. 2009;63(4):317-23. doi: 10.1136/jech.2008.078204

19. Xu X, Rao Y, Wang L, Liu S, Guo JJ, Sharma M, et al. Smoking in pregnancy: a cross- sectional study in China. Tob Induc Dis. 2017;15:35. doi: 10.1186/s12971-017-0140-0

20. Silva KMM, Souza DPO. Tabagismo: abuso físico parental e fatores associados entre pacientes dos ambulatórios do Hospital Universitário Júlio Muller, Cuiabá (MT), 2013. Cad Saúde Colet. 2013;21(4):370-6. doi: 10.1590/S1414-462X2013000400003

21. Giatras N, Wanninkhof E, Leontowitsch M, Lewis B, Taylor A, Cooper S, et al. Lessons learned from the London Exercise and Pregnant (LEAP) Smokers randomised controlled trial process evaluation: implications for the design of physical activity for smoking cessation interventions during pregnancy. BMC Public Health. 2017;17(1):85. doi: 10.1186/s12889-017-4013-5

22. Borland T, Babayan A, Irfan S, Schwartz R. Exploring the adequacy of smoking cessation support for pregnant and postpartum women. BMC Public Health. 2013;13:472. doi: 10.1186/1471-2458-13-472

23. Scheuermann TS, Richter KP, Jacobson LT, Shierman TI. Medicaid coverage of smoking cessation counseling and medication in underutilized for pregnant women. Nicotine Tob Res. 2017;19(5):656-9. doi: 10.1093/ntr/ntw263

24. Bull L. Smoking cessation intervention with pregnant women and new parents (part 2): A focus group study of health visitors and midwives working in the UK. J Neonatal Nurs. 2007;13(5):179-85. doi: 10.1016/j.jnn.2007.07.003

25. Hubbard G, Gorely T, Ozakinci G, Polson R, Forbat L. A systematic review and narrative summary of family-based smoking cessation interventions to help adults quit smoking. BMC Fam Pract. 2016;17:73. doi: 10.1186/s12875-016-0457-4 